\title{
KOBİ'lerde Yönetim Ve Maliyet Muhasebesinin Stratejik Karar Alma Üzerine Etkisi
}

\author{
Emin YÜREKLİ
}

\section{ÖZET}

Ekonomi ve teknoloji alanındaki değişimlerin son yıllarda hızlanmasıyla birlikte, KOBİler başta olmak üzere işletmelerin bu değişimi yakından takip etme zorunluluğu doğmuş̧ur. Yaşanan değişimler başta geleneksel maliyet muhasebesi olmak üzere yönetim muhasebesi üzerinde birtakım farklllikların oluşmasına neden olmuştur. Bu doğrultuda KOBİler bünyelerindeki maliyet ve yönetim muhasebe sistemlerinin yeterli olmadı̆̆ını görüp, sistemlerini yeniden gözden geçirilmesi gereksinimini duymuşlardır. Isşletmelerde alınan stratejik, yönetsel ve teknik kararların büyük bir kısmı maliyetlerle ilgilidir. Bu kapsamda, araştırmada yönetim ve maliyet muhasebesi uygulamalarının stratejik karar alma üzerine etkisi incelenmiştir.

KOBI'lerin stratejik karar almalarında yönetim ve maliyet muhasebesi uygulamalarının etkisine yönelik olarak Denizli Organize Sanayi Bölgesi'ndeki işletmeler özelinde gerçekleştirilen araştırmada KOBİlerin stratejik kararlarında yönetim muhasebesinin maliyet muhasebesine göre daha etkin kullanıldığı bulunmuştur. Araştırmamızda ayrıca ANOVA analizi sonucunda KOBI'lerde yönetim ve maliyet muhasebesinin stratejik karar alma üzerine etkisinde; sektörel farklllık başta olmak üzere, katılımcıların mesleki deneyimleri, işletmenin faaliyet süresi ve işletmenin faaliyet alanı gibi farklllık tespit edilen değişkenler incelenmiş ve ayrıntılı bir şekilde açıklanmıştır.

Anahtar Kelimeler: Yönetim Muhasebesi, Maliyet Muhasebesi, KOBİ'ler

JEL Siniflandırmast: M40, M41. \section{Making \\ The Effect of Management and Cost Accounting in SMEs on Strategic Decision}

\section{ABSTRACT}

With acceleration of changes in economy and technology in recent years, it is required for the companies, mainly SMEs to closely monitor these changes. The changes have given rise to certain differences in management accounting especially in conventional cost accounting. In this respect, SMEs have realized that their cost and management accounting systems are not adequate and therefore felt to revise their systems. Strategic, managerial and technical decisions made at the companies are generally related to the costs. Within this context, the impact of strategic decisions on the management and cost accounting practices were examined in this research.

With regard to the effect of strategic decision making on management and costs accounting practices, the study was conducted for the enterprises located at Denizli Organized Industrial Zone and it has been found that SMEs use management accounting more effectively than cost accounting when dealing with strategic decisions. In this study, the variables such as sectoral differences, professional experience of the participants, operation period and scope of activities of the company were examined through the ANOVA analysis regarding the effect of management and cost accounting on strategic decision making on SMEs and explained in detail.

Keywords: Management Accounting, Cost Accounting, SMEs.

Jel Classification: M40, M41.

\footnotetext{
*Yrd. Doç. Dr. Emin Yürekli, Kırgızistan-Türkiye Manas Üniversitesi, İktisadi ve İdari Bilimler Fakültesi.
} 


\section{GíRiş}

Sadece ülkemizde değil aynı zamanda dünyada da küçük ve orta ölçekli işletmeler (KOBİ) ticaret ve dolayısıyla ekonomi açısından oldukça önemlidir. TÜiK 2015 verilerine göre; küçük ve orta büyüklükteki işletmeler (KOBI) toplam girişim sayısının \%99,8'ini, istihdamın $\% 74,2$ 'sini, maaş ve ücretlerin $\% 54,7$ 'sini, cironun $\% 63,8$ 'ini, faktör maliyetiyle katma değerin (FMKD) \%52,8'ini ve maddi mallara ilişkin brüt yatırımın \%53,3'ünü oluşturmaktadır. Ayrıca KOBİ'ler ihracatın \% 56,4'ünü ve ithalatın ise \%37,8'ini gerçekleştirmektedirler.

Rekabet koşullarının giderek arttığı ortamda, KOBI'lerin rekabet edebilir mamul ve hizmetleri üretebilmesi için finansal bilgiyi toplayarak, yönetime planlama başta olmak üzere stratejik yönetim kararları için gerekli bilgiyi sağlamaları gerekmektedir. $\mathrm{Bu}$ rekabet ortamında maliyet ve yönetim muhasebesinden yönetim sürecinden faydalanma anlayışı da farkl11ık göstermiştir. Ekonominin temelini oluşturan KOBİ'ler, bünyelerindeki mevcut aksaklıkları giderebilmek için kıt kaynakları en verimli şekilde kullanmak ve farklı vadelerde stratejik opsiyonlara sahip olmak durumundadır. $\mathrm{Bu}$ nedenle KOBİ yönetimlerinin organizasyon hedefleri için stratejik karar alma uygulamalarına başvurabilmeleri ve bu uygulamaları değerlendirmeleri büyük öneme sahiptir. Bu çalışma kapsamında da KOBI'’lerde yönetim ve maliyet muhasebesi uygulamalarının stratejik karar alma üzerindeki etkilerinin değerlendirilmesi amaçlanmaktadır. Bu amaçla, Denizli Organize Sanayi Bölgesi özelinde bir araştırma gerçekleştirilmiştir. Araştırmada KOBI'lerin stratejik karar alımlarında yönetim ve maliyet muhasebesi uygulamalarının etkilerinin değerlendirilmesi amacıyla çeşitli akademik araştırmalardan, araştırmamızın amacına uygun olarak derlenmiş anket soruları yardımıyla bir anket çalışması gerçekleştirilmiş̧ir.

Araştırmanın metodolojisinin ana ekseninde anket uygulanmış olup, KMO testi, güvenilirlik analizi başta olmak üzere birtakım istatistiksel analizlerle anketin anlamlı ve güvenilir sonuçlar verdiği görülmüştür. Anket sonucunda ise yönetim ve maliyet muhasebesinin stratejik karar alma üzerinde doğrudan etkisi olduğu sonucuna ulaşılmış, yönetim muhasebesinin maliyet muhasebesine göre stratejik karar almada daha etkin şekilde kullanıldığı tespit edilmiştir. Ayrıca ankette maliyet ve yönetim muhasebesinin karar alma üzerine etkisini, katılımcıların öğrenim durumları,yaşları,mesleki deneyimleri ile işletmenin faaliyette bulunduğu sektör, faaliyet süresi, maliyet izleme birimi olup olmadığı gibi farklılık tespit edilen değişkenler incelenmiştir. Yapılan ANOVA analizleri sonucu işletmenin faaliyette bulunduğu sektör dışında analizi yapılan değişkenlerin farklılık göstermediği sonucuna ulaşılmıştır.

\section{LITERATÜR ARAŞTIRMASI}

Maliyet muhasebesi ile yönetim muhasebesi arasındaki ilişki Titiz ve Çetin (2000) tarafından yapılan çalışmadan yola çıkarak şu şekilde ifade edilebilir; maliyet muhasebesinin yıllar içinde küresel değişimlerden etkilenerek daha kapsamlı haline yönetim muhasebesi 
denir. Bu kapsamda yönetim muhasebesini, planlamada, karar vermede, şirket yönetimini kontrol altında tutmayı destekleyen muhasebenin bir dalı olarak tanımlayabiliriz (Mihăilă, 2014: 1199). Ayrıca maliyet muhasebesini işletme içi kararlarda doğru pozisyon almayı sağlamak için kullanılırken, günümüzde işletme dışı kararlar almada kullanılan haline yönetim muhasebesi demek de mümkündür. Bayri (2005) tarafından yapılan çalışmada, işletmelerin işletme içi faktörler kadar işletme dış1 faktörlere de önem vermesi gerektiği ifadesi yönetim muhasebesi açısından önemlidir. Bununla birlikte, yönetim muhasebesi kavramının son yıllarda öneminin giderek arttığı ve yönetim muhasebesinin organizasyonu kontrol etme üzerindeki etkisi üzerinde durulduğu ifade edilmiştir (Dekker, 2016: 86). Ma ve Tayles (2009) tarafından yapılan çalışmada, son yıllarda ülkelerin yaşamış olduğu ekonomik krizlerde, geleneksel yönetim muhasebesinin üzerinde etki gösterdiği ve değişiklikler yaşanmasına neden olduğuna vurgu yapılmıştır. Ayrıca bu değişikliklerin stratejik karar alma gerekliliğini de ortaya koyduğu belirtilmiştir.

Laitinen (2014) tarafından yapılan çalışmada, maliyet muhasebesinin yönetim muhasebe sistemlerinden en önemlilerinden birisi olarak tanımlanması önemlidir. Maliyet muhasebesindeki değişiklikler yönetim muhasebesini pozitif yönde etkilemiştir. Bu bağlamda, Jänkälä ve Silvola (2012) ve Maiga ve Jacobs(2008) tarafından yapılan çalışmaların da desteklediği "Maliyet muhasebesindeki değişikliler yönetimin operasyonel iyileştirmeler yapması ve stratejik kararları yönlendirmesi açısından önemlidir” tespiti maliyet muhasebesi, yönetim muhasebesi ve stratejik karar alma kavramları arasındaki ilişki açısından önemlidir. Altuğ (2006) tarafından yapılan çalışmada ise, “..maliyet muhasebesinin yönetim açısından planlama ve kontrol süreçleri başta olmak üzere elde ettiği verileri kullanılabilir hale getirmesi yönetim muhasebesini oluşturur” ifadesi iki kavramın ilişkisini ortaya koyması açısından önemlidir.

Demir (2008) tarafından yapılan çalışmada, stratejik yönetim muhasebesi kavramının, yönetim muhasebesinin strateji kavramı ile birleşmesi ortaya çıktığına vurgu yapılmıştır. Aynı çalışmada, yönetim muhasebesindeki değişimlerin işletmelerde karar verme sürecini etkilediği birçok çalışma tarafından ortaya konduğu ifade edilmiştir.

Hatunoğlu vd. (2013) tarafından yapılan araştırmaya Gaziantep ve Kahramanmaraş'tan 74'er KOBİ katılmıştır. Elde edilen sonuçlara göre, muhasebe bilgi sistemi tarafından üretilen bilgilerin yöneticiler tarafindan planlama faaliyetlerinde kullanıldığı ve hazırladığı raporların en fazla finansman departmanı, en az ise üretim departmanı tarafından kullanılmakta olduğu sonucuna ulaşılmıştır. Yazıcı (2010) tarafından yapılan çalışmada, literatürde yer alan KOBİ'ler ve muhasebe bilgi sistemi konulu çalışmalarda KOBİ'lerin muhasebe bilgi sisteminin önemine yönelik farkındalık düzeylerinin düşük olduğunu belirtmesi bu kavramların önemi üzerinde durmamız gereğini ortaya koyduğundan önem taşımaktadır.

Stratejik yönetim muhasebesi kavramı 1980'lerin öncesinde ortaya çıkmış ve ilk olarak Simmonds (1981) tarafından yapılan çalışmada yer verilmiştir. Titiz ve Çetin (2000) 
tarafından yapılan çalışmada, stratejik yönetim muhasebesi kavramının geçerli bir tanımı olmadığı vurgulanmıştır. Simmonds (1981) tarafından yapılan çalışmada, stratejik yönetim muhasebesi kavramı yönetim muhasebesi verilerinin hazırlanması ve analizi ile rakip işletmelere yönelik strateji geliştirmek ve izlemek amaçlı kullanılmıştır. Stratejik yönetim muhasebesinin hedeflerini şu şekilde sıralayabiliriz (Hilton, 1999: 5):

$\checkmark \quad$ Karar alma, planlama ve karar alma sürecine etkin katılım için bilgi sağlama ve stratejik planlama süreci,

$\checkmark \quad$ Yöneticilere operasyonel faaliyetlerin yönlendirilmesi ve kontrolünü sağlama,

$\checkmark \quad$ Yöneticileri ve diğer kullanıcıları organizasyonun amaç ve hedeflerine doğru motive etmek,

$\checkmark \quad$ Faaliyetlerin, alt birimlerin, yöneticilerin ve diğer kullanıcıların performansını ölçmek.

$$
\text { Organizasyon yapmak. }
$$

Al Maryani ve Sadık (2012) tarafından yapılan çalışmada, bugünün iş dünyasında kuruluşlar için stratejik yönetim teorilerinin ve fikirlerinin uygulanmasının hayatta kalmak ve varlıklarını devam ettirmek için önemli hale geldiğinden bahsedilmiştir. Bunun da stratejik yönetim muhasebesi ile sağlanacağı aynı çalışmada ortaya konmuştur.

Zenita vd. (2015) tarafından yapılan çalışmada, stratejik yönetim muhasebesinin yöneticiler üzerinde olumlu etki sağladığı tespiti yönetim muhasebesi ve stratejik karar alma kavramları arasındaki ilişkiyi göstermesi açısından önemlidir. Ayrıca stratejik yönetim muhasebesinin kullanımı strateji ve organizasyon performansını geliştirdiği söylenebilir (Ah Lay ve Jusoh, 2011).

İşletme yönetiminde karar alma, iyi veya kötü, doğru veya yanlış kısacası seçim yapma ile eş değerdir (Koçel, 2003: 76). İşletmelerde karar alınamıyor ise, kaynak kullanımı bilinmiyor ve en önemli maliyet unsuru olan zaman kavramı düşünülmüyor demektir (İzci, 2014: 190). Karar alma süreci telafisi olmayan zaman gibi kaynakların kullanımı için stratejik öneme sahiptir. Bu nedenle yöneticilerin karar almaları ortaya konan durumun karmaşıklı̆̆ ve zorluğuna göre değişmektedir (Ehtiyar ve Tekin, 2010: 3395). Karar verme süreci Koçel (2013) tarafindan yapılan çalışmada:

$\checkmark \quad$ Amaç veya sorunun belirlenmesi,

$\checkmark \quad$ Amaç veya soruna göre önceliklerin tespiti,

$\checkmark \quad$ Çözüme alternatifler belirleme,

$\checkmark \quad$ Belirlenen alternatiflerin değerlendirilmesi

$\checkmark \quad$ Seçim kriterlerine göre kararın verilmesi şeklinde aşamalandırılmıştır. 
Şekil 1. Yönetsel Karar Alma Süreci

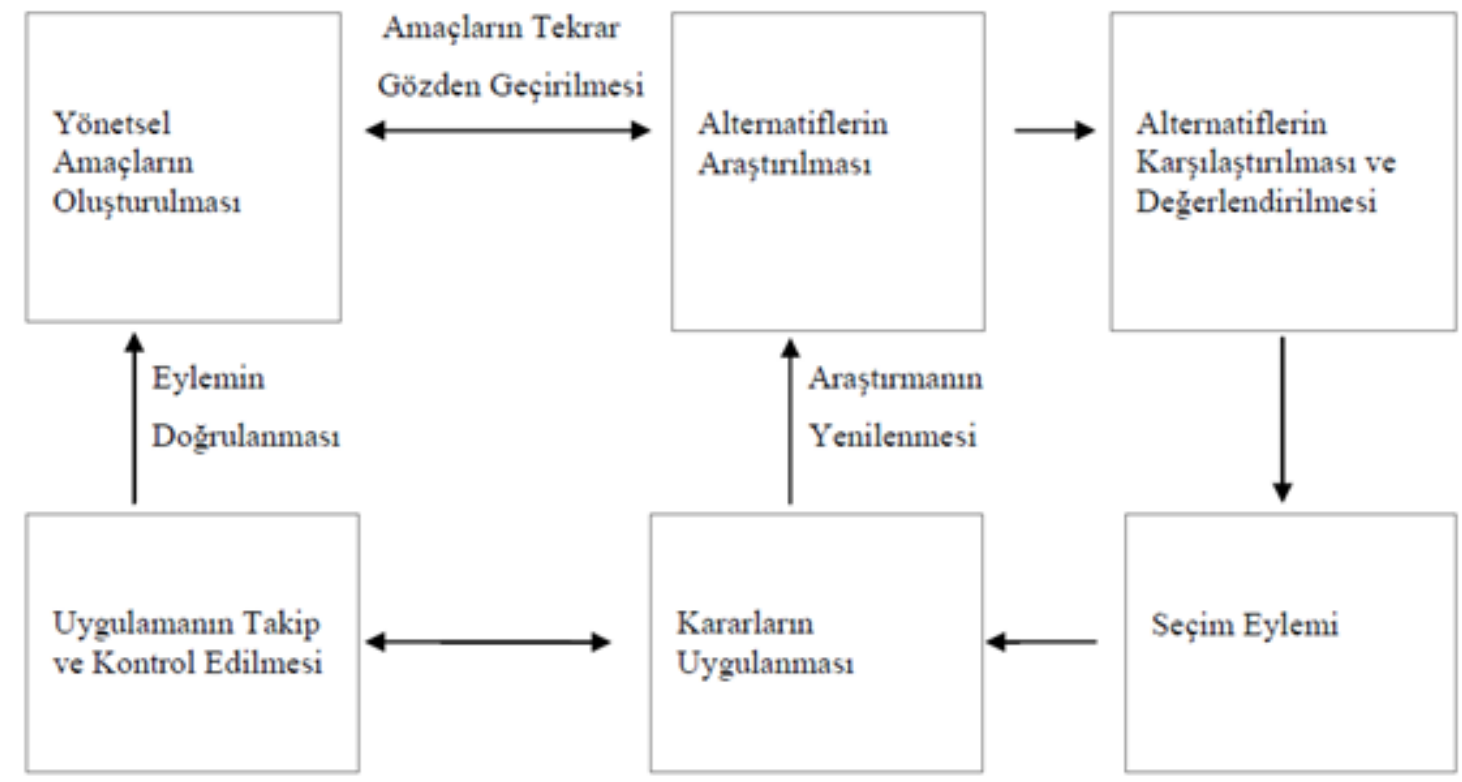

Kaynak: Harrison ve Pelletier, 2000: 463: Akt: İzci, 2014: 191

İzci (2014) tarafından yapılan çalışmada, işletmelerin değişen koşullar altında sürdürülebilir bir yapıya sahip olmaları açısından karar alma sürecinin önemine değinilmiştir. Ayrıca muhasebe verilerinin işletmelerin rakip işletmeler ve kendi iç işleyişlerinin sağlıklı olması için gerekliliği vurgulanmıştır. Bu bakımdan işletmeler için maliyet ve yönetim muhasebesi etkin olursa stratejik kararlar alınabilir ve değişen koşullar işletme varlığını tehdit edemez diyebiliriz.

\section{BILLGI YÖNETIMİ AÇISINDAN YÖNETIM VE MALIYET MUHASEBESI}

Günümüzde sürekli büyüyen ve değişimlerin ayaklarını oluşturan bilgi ve büyük veri (bigdata), işletmeleri de bu doğrultuda bilgi ve veriyi doğru bir şekilde değerlendirmeye yönlendirmektedir. Bu kapsamda muhasebe bilgi sistemleri, bilginin temel bir elemanı olarak işletme devamlılı̆̆ ve faaliyetlerin gelecek koşullara uyumu için dikkatli bir şekilde planlamayı gerektirmektedir. Bilgi yönetimi açısından yönetim ve muhasebe bilgi sistemleri; geleneksel muhasebenin yanında yönetim muhasebesi, maliyet muhasebesi, sorumluluk muhasebesi, işletme bütçesi gibi yönetim faaliyetlerini kapsayan geniş bir sistemler bütünüdür.

Ekonomik ve teknolojik değişimler ve bunların işletmeler üzerine etkileri günümüz işletme yöneticilerini karar almada kullanacakları muhasebe bilgilerinin kapsamını ve niteliğini de büyük ölçüde değiştirmiştir (Saban ve Erdoğan,2014:532)

Küreselleşme ile birlikte rekabet ortamının kızışması yönetim muhasebesini; tüm kuruluşlar için önemli bir fonksiyon durumuna getirmiştir. Ekonomik amaç gütsün ya da 
gütmesin tüm kuruluşların stratejik hedefler ortaya koymaları ve bu hedeflere ulaşmalarında yönetim muhasebesi en önemli araçlardan birisi olmalıdır(Davilo, Lopez ve Rubio, 2015: 116). Yönetim muhasebesi stratejik planlama, paydaşlarla ilişkilerde ve üretim planlamada aktif rol oynamaktadır. Yönetim muhasebesi, organizasyonlarda yöneticilere karar verme sürecini operasyon performansı, maliyetler ve faydalar hakkında düzenli analizler sunulmasına da olanak tanımaktadır. Yönetim için bilgi sistemi olan yönetim muhasebesi, iş sağlığı ve güvenliği alanında karar vermeyi kolaylaştırmak için sistemli biçimde rapor sunulmasını da sağlamaktadır (Davilo, Lopez ve Rubio, 2015: 117).

Teknoloji uygulamalarının her alanda artış göstermesinin ardından muhasebe uygulamaları, basit yasal yükümlülükleri yerine getirmenin ötesinde bir anlam kazanmaya başlamıştır. Muhasebede bilgisayar kullanımının artışı, tüm işletmelerde muhasebe verilerini bilgisayar ortamında kayıt etmelerine olanak tanımıştır. Muhasebenin temel işlevlerinden olan raporlama sayesinde ise ,işletme yönetiminin karar almasında gerekli veriler sağlanmış ve bu verilerin sonuçlarının yeniden yönetime sunulması imkânı oluşmuştur (Demir ve Gül, 2015: 172). Bu veriler 1şığında maliyet muhasebesi; endüstriyel faaliyette bulunan veya hizmet üreten işletmelerin ürettikleri mamullerin maliyetini belirlemek için maliyet unsurlarının türlerini, ortaya çıktıkları yerler itibariyle ve üretilen mamullerin türlerine göre izlemek için yapılan hesaplar ve tutulan kayıtları kapsamaktadır (Yükçü, 1998: 3).

İşletme yönetimi için en sağlıklı ve yararlı bilgiyi maliyet muhasebesi bilgi sistemi üretmektedir ve maliyet muhasebesi ile elde edilen verilerin yararlı olmasının yanı sıra bu verilerin etkin ve verimli biçimde yorumlanarak, karar vericilere sunulmasını gerektirmektedir. İşletme geleceği için karar verici konumundaki yöneticilerin bilgiye olan ihtiyacı sonucunda; muhasebe bilgilerinin en uygun zamanda, en doğru ve en uygun biçimde iletilmesi yönündeki çabalar yoğunlaşmış ve dolayısıyla bu süreçte maliyet muhasebesine olan gereklilik de artmıştır (Demir ve Gül, 2015: 172).

\section{STRATEJIKK KARAR ALMA}

Stratejik yönetim, tanımı gereği en etkin kararların alınması ve uygulanması üzerine odaklanan bir yönetim tekniği durumunadır. Aktan (2008: 6)'a göre stratejik yönetim, organizasyonlarda geleceğe yönelik kararlar alınmasında kullanılan bir yönetim tekniğidir. Bir başka tanımlamaya göre stratejik yönetim "etkili stratejiler geliştirmeye, uygulamaya ve sonuçlarını değerlendirerek kontrol etmeye yönelik kararlar ve faaliyetler bütünü” (Karaoğlu, 2010: 61) olarak açıklanmaktadır. Yüzbaşıoğlu (2004: 389) tarafından yapılan çalışmaya göre

ise, stratejik yönetim "organizasyonun hedeflerine ulaşmasını sağlayacak fonksiyonel kararların kesin ve açık olarak anlatılması, bütünlüğün tamamlanması ve değerlendirilmesi bilimi” şeklinde tanımlanmaktadır.

Tanımlardan da anlaşılacağı üzere stratejik yönetimin bir süreci olarak stratejik karar alma, işletmelerin doğru bir şekilde karar vermesi ve bunu uygulamasını da gerektirmektedir. Bunun temel nedenleri ise stratejik kararların geleceği ilgilendirmesi nedeni ile belirsizlik 
taşıması; alınacak kararların bütünü ilgilendirmesi ve stratejik yönetimin beraberinde birçok sorunu da getiren değişim sürecini gerektirmesidir (Yüzbaşığlu, 2004: 389).

İşletmelerde bir tür stratejinin uygulanması şüphesiz karar verme davranışı ile açıklanmaktadır. Ekonomi biliminde karar vermenin özü, ekonomik seçim işlemi olmuştur. $\mathrm{Bu}$ nedenle ekonomistler, insanın rasyonel kararlar verebileceği varsayımından hareket etmişlerdir. Onlar için ekonomik insan, rasyonel karar vermeyi, yani strateji içerisinde tüketici açısından en büyük yararı üretici açısından büyük kazancı sağlamayı bilen ve seçen kişidir (Demir ve Gümüşoğlu, 1998: 80).

Günümüzün yoğun rekabet ortamında, işletme yöneticilerinin sağlıklı kararlar almaları, işletme amaçlarını gerçekleştirmeleri açısından son derece önemlidir. Karar alma, alternatifler arasından seçim yapmayı gerektiren bir süreçtir. Yöneticiler, alternatifler arasından seçim yaparken karar seçeneklerine ilişkin bilgilere ihtiyaç duyarlar. İşte, yönetim muhasebesi, işletme yöneticilerine karar alma süreçlerinde kullanmak üzere ihtiyaç duydukları sayısal bilgileri sağlayan bir disiplindir (Aktaş, 2013: 57).

Birçok yönetim kararı, maliyet kararı, maliyet bilgisine dayanmaktadır ya da ondan etkilenmektedir. Duruma bağlı olarak, maliyetler; karar verme süreci ile ilişkili ya da ilişkisiz olabilir. Bir sonraki maliyet sınıflandırması, karar verme süreci için maliyetlerin nasıl sınıflandırılacağına rehberlik etmektedir (Oliver, 1999: 28).

\subsection{Stratejik Yönetim Süreci}

Stratejik yönetim işletmelerin üst yönetiminin karar vermesi gereken ve işletmelerin gelecek ile ilgili planlarının yer aldığı bir üst yönetim fonksiyonudur. İşletmeyi bir bütün olarak düşünecek olursak işletmelerin geleceği ve gelecek ile ilgili hedeflerin belirlenmesi üst yönetimin vereceği kararlar ile belirlenir. Üst yönetim bu kararları alırken işletmenin tüm bileşenlerini göz önüne alarak, bütünleşik yapının işletme hiyerarşisi içindeki etkileşimi göz önünde bulundurarak almalıdır. Bu sebeple stratejik yönetim çevreyi oldukça yakından takip eder. Aynı zamanda stratejik yönetim, işletme kaynaklarının en etkili bir şekilde dağıtımıyla ilgilidir. İşletmenin temel amaçlarının gerçekleştirilebilmesi için gerekli kaynakları mamul/pazar bileşimlerine uygun bir şekilde dağıtır (Bosemann ve Phatak, 1989: 14, 16).

Stratejik yönetim sürecinin asıl amacı temel alternatif stratejiler arasından işletmenin amaç ve hedeflerine en uygun olanının seçimini içerir. Bu aşama aynı zamanda bir değerlendirme ve karar alma aşamasıdır. Tüm karar alma olaylarında olduğu gibi alternatif stratejilerin değerlendirilmesinde, her bir alternatifin kısa vadede ve uzun vadede işletmeye sağlayacağı getiriler ve yükleyeceği maliyetlerin analizinin de yapılması gereklidir. Stratejik alternatifler arasından en uygun olanının seçimi şu kıstaslar dikkate alınarak yapılır (Wheelen ve Hunger, 1989: 226, 227: İzci, 2014: 193):

$\checkmark \quad$ Var olan strateji, organizasyonda bulunan diğer stratejilerle çatışıyor mu?

$\checkmark \quad$ Piyasa koşullarında seçilecek stratejinin zamanlaması doğru mu? 


\author{
$\checkmark \quad$ Oluşturulacak strateji, rekabetçi bir ortam da varlığını sürdürmeye devam \\ edebilecek mi?
}

$\checkmark \quad$ Strateji çeşitli finansal teknikler (net nakit akışı, sermaye karlılı̆̆ı, geri ödeme dönemi, başa baş analizi, iskonto edilmiş nakit akışı) ve fayda maliyet analizlerine göre test edildi mi?

$\checkmark \quad$ Strateji, örgütte birbiriyle düzgün bir şekilde ilişkili alt stratejilere bölünmüş durumda mi?

İşletme yönetiminin belirlemiş olduğu bu stratejilerden sonra maliyet ve yönetim muhasebesinin stratejik hedefe doğru uygulama aşaması başlar ve üst yönetim hedefe doğru ilerlemeye çalışır. Hedefe ulaşmada çevresel faktörlerle birlikte işletmenin bütünleşik sisteminin bu organizasyonda oldukça önemli bir yeri vardır ve üst yönetimin en önemli görevlerinden bir tanesi de bu organizasyonu başarı ile yönetmektir.

\title{
4.2. KOBİ’lerde Stratejik Karar Almanın Önemi
}

KOBI'lerin sahip olduğu en önemli avantajlar, esneklik, yoğunlaşma ve işletme içi haberleşme konularında ortaya çıkmaktadır. Pazarlama, üretim ve AR-GE konularında karar verme sürecinde etkin davranabilme becerisi, küçük işletme ortamında daha kolay sağlanabilmektedir (Akgemci, Öğüt ve Tosun, 2005: 157).

KOBI'lerde karar verme süreci gayet dinamiktir. Gibcus ve vanHoesel (2004:5) tarafından yapılan bir araştırmada, KOBİ türü firmaların yaklaşık\%65'inin,araştırma dönemi öncesindeki üç yıl içerisinde önemli kararlar aldıkları ve yakın gelecekte de önemli kararlar alabilecekleri ortaya konulmuştur.Bu nedenle KOBİ'lerde stratejik kararlar alma ve bunları uygulayabilme büyük öneme sahiptir.

KOBİ'lerde stratejik karar alma konusunda özellikle stratejik planlamanın da önemli bir rolü bulunmaktadır. Buna göre özellikle KOBİ'lerin yaşamlarını sürdürmesi ve büyümesi ile stratejik planlama yaklaşımının benimsenmesi arasında sıkı bir ilişki vardır. Bu bağlamda KOBI'lerin stratejik kararlarında maliyet ve yönetim muhasebesinin önemli bir faktör olduğu bilinmektedir.

\subsection{KOBİ'lerde Yönetim ve Maliyet Muhasebesi ve Stratejik Karar Alma İlişkisi}

Karar verme üzerine yapılan değerlendirmelerin birçoğu büyük firmalar üzerine yoğunlaşmıştır. Oysa ekonominin temel direği olan küçük işletmeler için de karar alma süreci büyük öneme sahiptir. Bu konuda yapılan çalışmalara göre, küçük firmalarda karar alma önyargıları ve sezgisel kullanımının daha hassas olduğu belirtilmiştir, bunun dışında birçok uygulama çalışmasında da profesyoneller ve girişimciler tarafından yönetilen işletmelerin farklılıklarına odaklanılmıştır (Gibcus, Vermeulen ve Jong, 2004: 4).

Geleneksel yönetim ve maliyet muhasebesi sistemleri daha çok finansal raporlama ve gerekli stok değerlemeleri için tasarlandığından, yönetimin karar almada ihtiyaç duyduğu 
bilgileri sağlayamamaktadır. Öte yandan karar almak için kullanılacak sayısal bilgi gereksinimi arttığı gibi istenilen bilgilerin niteliğinde de büyük değişim olmuştur. Yönetim ve maliyet muhasebesi, işletme stratejisinin ve uygulama planlarının hazırlanması, işletmenin yönetilmesinde kullanılan finansal bilgilerin tanımlaması, ölçülmesi, toplanması, kısaca stratejik karar alma için ihtiyaç duyulan bilginin üretilmesinden ve işletmenin kaynaklarının en uygun şekilde kullanılmasından sorumludur. Yönetim ve maliyet muhasebesi, çoklukla işletme içine yönelik olduğundan, genel kabul görmüş prensiplerle sınırlanmak zorunda değildir. Ancak birçok KOBI'de maliyetlerin ayrıntılarına pek fazla girilmediği, genelde toplam maliyetlerle kararların alındığı ve işlerin yürütüldüğü bilinmektedir. Nedeni araştırıldığında, ayrıntıların pek de önemli olmadığı, daha çok sonuçların önemi olduğu, bu işletmelerin birçoğunda da üretim planlarına, verimlilik analizlerine fazla yer verilmediğinden kaynaklandığı görülmüştür.

Tablo 1. Bilgi Sistemleri

\begin{tabular}{|c|c|c|}
\hline Bilgi Kullanıcılar & Sağlanan Finansal Bilgiler & Desteklenen kararlar \\
\hline Yatırımcilar & Kârlılık & Performans değerlendirme \\
\hline Borç Verenler & Finansal Durum & Menkul kıymetyatırımları \\
\hline Yöneticiler & Nakit Akımları & Vergi stratejileri \\
\hline Hissedarlar & & İşgücü ilişkileri \\
\hline Müşteriler & & Kaynak tahsisi \\
\hline Çalışanlar & & Borç verme kararları Borç alma \\
\hline Düzenleyici kurumlar & & kararları \\
\hline SPK & & \\
\hline Gelirler İdaresi Çevre Bakanlığı & & \\
\hline
\end{tabular}

Kaynak: (Alagöz, Öge ve Koçyiğit, 2013:31)

Yönetim ve muhasebe bilgisinin yorumlanması, stratejik karar alma sürecinde önemli rol oynamaktadır. $\mathrm{Bu}$ nedenle bu yönde bir sinıflandırmanın karar alma ve kullanıcı tercihlerindeki etkileri ortaya koyması bakımından önemli kabul edilmektedir. Alagöz, Öge ve Koçyiğit (2013: 35-36)'in belirttiği gibi, muhasebe verilerini kullanarak karar veren üç temel sınıf bulunmaktadır. İlk grupta işletme içinde hem faaliyetlerle hem de finansal raporları hazırlayan muhasebe sistemi ile ilgili karar verenler (üst yönetim) bulunmaktadır. İkinci grupta, faaliyetlerle ilgili karar veren; muhasebe bilgisini değiştiremeseler de aldıkları kararların getirdiği sonuçlar dolaylı olarak muhasebe sistemini etkileyenler bulunmaktadır. Üçüncü grup ise, firmanın dışında olan ve kararlarıyla firmanın çevresi ve faaliyetlerini 
etkileyen ama firmanın faaliyetleri ve yaptığı işler üzerinde doğrudan kontrolü olmayanlardan oluşmaktadır (Alagöz, Öge ve Koçyiğit, 2013: 36).

Konunun literatürde işılenişi dışında, uygulamalı çalışmalarda da stratejik karar verme sürecine ilişkin değerlendirmelerde bilgi sistemi, yönetim ve maliyet muhasebesi konularına odaklanılmıştır. Araştırmaların geneli, KOBİ'lerde stratejik önemdeki konularda karar verme konusunda muhasebe bilgisinden yeterince faydalanılmadığını ortaya koymaktadır.

Chang vd. (2015), Tayvan'da KOBİ'lerde maliyet muhasebenin karar verme üzerindeki etkisinin değerlendirildiği uygulama çalışmalarında, maliyet muhasebesi sisteminin yatırımlar özelinde işlevsiz karar vermeyi azalttığını; doğrudan enerji ya da malzeme israfını azaltarak yöneticilere yardımcı olduğunu değerlendirilmiştir.

Demir ve Gül (2015)'ün KOBİ'lerde karar verme sürecinde muhasebe bilgi sistemi etkilerini araştırdıkları çalışmada, 210 firmaya ulaşılmıştır. Elde edilen sonuçlara göre; işletmelerin strateji oluşturmalarında, misyon ve vizyon belirlemede muhasebe bilgi sistemi ile bu sistemin unsurları olan maliyet ve yönetim muhasebesinin de yeteri kadar öneminin olmadığı görülmüştür (Demir ve Gül, 2015: 190).

Yazıc1 (2010), muhasebe bilgi sistemlerinin KOBİ'lerin yönetim kararlarını etkileme düzeyini, Erzurum Organize Sanayi Bölgesi'nde faaliyet gösteren 45 işletmeye anket uygulayarak incelemiştir. Buna göre işletmelerin yönetim kararlarında muhasebe bilgi sisteminden faydalanma düzeyini gösteren faktörler açısından ise genel bir iyileştirme gerektiği belirlenmiştir.

Canbaz (2014)'ın Edirne ili üzerine yaptığı araştırmada, yönetim bilgi sistemi kullanan işletmelerin fonksiyonları dâhil stratejik planlama süreci üzerinde kurumsal etkinlik dışında, karar alma, üretim ve maliyetlerin yönetilmesi ile yatırım ve finansman için alınan kararlarda anlamlı etkisi olduğu; stratejik karar alma üzerinde ise kurumsal etkinlik dışında bir etkisinin olmadığ sonucuna ulaşmıştır.

Kalkan ve Keskin (2005), KOBİ'lerde bilgi yönetimi araçlarının kullanım yaygınlığını ölçtükleri çalışmalarında, Gebze ve çevresindeki 218 KOBİ’ye ulaşmışlar; elde edilen bulgulara göre KOBİ'lerde bilgi yönetimi araçlarının düşük oranlarda kullanıldıkları, dolayısıyla bu işletmelerde etkin bir bilgi yönetimi sürecinin yürütülmediğini ortaya koymuşlardır.

\section{ARAŞTIRMANIN METODOLOJISİ}

Araştırma, Denizli Organize Sanayi Bölgesi'nde toplam 47 işletme üzerinde uygulanmıştır. Araştırma kapsamında yapılan anketleri işletmelerin mali işler müdürü cevaplamıştır. Yapılan KMO Testi ve güvenilirlik analizi sonucunda anket formunun yapısal geçerliliği ve güvenilirliği onanmıştır. Yapısal geçerliliğinin ve güvenilirliğinin onanması ile birlikte istatistiksel analizlere geçilmiştir. Öncelikle Normallik Analizi ile verilerin normal dağılıma uygunluğu test edilmiş, verilerin normal dağılım göstermesi üzerine parametrik 
analizlerin kullanılmasına karar verilmiştir. Parametrik testlerden iki gruplu olan değişkenler için Bağımsız Örneklem T Testi (Independent Samples T Test), ikiden fazla gruplu olanlar için ise ANOVA analizi yapılmıştır. ANOVA analizi sonucunda farklılık tespit edilen değişkenler için farklılığın kaynağı ise Tukey Çözümlemesi yardımıyla test edilmiştir. Yapılan tüm analizler, SPSS for Windows 23.0 paket programı ile gerçekleştirilmiştir.

Araştırmada yönetim muhasebesi uygulamalarının ve maliyet muhasebesi uygulamalarının stratejik karar alma üzerine etkisi araştırılmıştır. Bu kapsamda verilerin toplanabilmesi için yönetim muhasebesi uygulamalarının stratejik karar alma üzerine etkisi ile maliyet muhasebesi uygulamalarının stratejik karar alma üzerine etkisi konulu çeşitli akademik araştırmalarda kullanılan ölçeklerde yer alan ifadeler, sadeleştirilerek ve birleştirilerek kullanılmıştır. Anket formunda yer alan maliyet muhasebesi uygulamaları ve yönetim muhasebesi uygulamalarına ait toplam 25 durumun stratejik karar alma üzerine etkisini ölçmek amaciyla karma bir anket formu oluşturulmuştur. Anketten alınabilecek en düşük puan 25, en yüksek puan 125 olup, puan ortalamalarının ifade ettiği aralıklar Tablo 2'deyer almaktadır (Boran, 2015: 205).

Tablo 2. Puan Ortalamaları

\begin{tabular}{|l|c|l|}
\hline Hiç Etkili Değil & 1,01 & 1,80 \\
\hline Etkili Değil & 1,81 & 2,60 \\
\hline Kararsızım & 2,61 & 3,40 \\
\hline Etkili & 3,41 & 4,20 \\
\hline Çok Etkili & 4,21 & 5,00 \\
\hline
\end{tabular}

Kaynak: (Boran, 2015: 205)

\subsection{Araştırmanın Amacı}

$\mathrm{Bu}$ araştırma, yönetim muhasebesi ve maliyet muhasebesi uygulamalarının KOBI'lerin stratejik karar alma süreçleri üzerindeki etkilerini ortaya koymak amaciyla gerçekleştirilmiştir. Bu amaçla hazırlanan anket formu ile toplanan veriler ile aşağıdaki hipotezler test edilecektir.

H1: Yönetim muhasebesi uygulamaları stratejik karar alma üzerine etkilidir.

H11: Katılımcıların yönetim muhasebesi uygulamalarının stratejik karar alma üzerine etkisine yönelik görüşleri yaşlarına göre farklılık göstermektedir.

H12: Katılımcıların yönetim muhasebesi uygulamalarının stratejik karar alma üzerine etkisine yönelik görüşleri eğitim durumlarına göre farklılık göstermektedir.

H13: Katılımcıların yönetim muhasebesi uygulamalarının stratejik karar alma üzerine etkisine yönelik görüşleri mesleki deneyimlerine göre farklılık göstermektedir. 
H14: Katılımcıların yönetim muhasebesi uygulamalarının stratejik karar alma üzerine etkisine yönelik görüşleri firmasının faaliyet süresine göre farklılık göstermektedir.

H15: Katılımcıların yönetim muhasebesi uygulamalarının stratejik karar alma üzerine etkisine yönelik görüşleri firmasının faaliyet alanına göre farklılık göstermektedir.

H16: Katılımcıların yönetim muhasebesi uygulamalarının stratejik karar alma üzerine etkisine yönelik görüşleri firmasında ayrı bir maliyet izleme birimi olup olmamasına göre farklılık göstermektedir.

H2: Maliyet muhasebesi uygulamaları stratejik karar alma üzerine etkilidir.

H21: Katılımcıların maliyet muhasebesi uygulamalarının stratejik karar alma üzerine etkisine yönelik görüşleri yaşlarına göre farklılık göstermektedir.

H22: Katılımcıların maliyet muhasebesi uygulamalarının stratejik karar alma üzerine etkisine yönelik görüşleri eğitim durumlarına göre farklılık göstermektedir.

H23: Katılımcıların maliyet muhasebesi uygulamalarının stratejik karar alma üzerine etkisine yönelik görüşleri mesleki deneyimlerine göre farklılık göstermektedir.

H24: Katılımcıların maliyet muhasebesi uygulamalarının stratejik karar alma üzerine etkisine yönelik görüşleri firmasının faaliyet süresine göre farklılık göstermektedir.

H25: Katılımcıların maliyet muhasebesi uygulamalarının stratejik karar alma üzerine etkisine yönelik görüşleri firmasının faaliyet alanına göre farklılık göstermektedir.

H26: Katılımcıların maliyet muhasebesi uygulamalarının stratejik karar alma üzerine etkisine yönelik görüşleri firmasında ayrı bir maliyet izleme birimi olup olmamasına göre farklılık göstermektedir.

\subsection{Evren ve Örneklem}

Araştırma Denizli Organize Sanayi Bölgesi özelinde uygulanmıştır. Bu nedenle araştırmanın evrenini, Denizli Organize Sanayi Bölgesi’nde faaliyet gösteren toplam 151 işletme oluşturmaktadır. Anket çalışması için tüm işletmelere formlar gönderilmiş ve işletmelerin mali işler müdürünün yanıtlanması istenmiştir. Toplam 151 işletmeden 84 tanesi anket formunu yanıtlamış ve teslim etmiştir, 67 firma ise ankete katılmayı reddetmiştir / katılmamıştır. Toplanan 84 anket formundan ise 47 tanesi anketi eksiksiz olarak doldurduğundan geçerli kabul edilmiş, geri kalan anketler araştırma dışında bırakılmıştır. $\mathrm{Bu}$ nedenle araştırmanın örneklemi 47 işletmeden oluşmaktadır.

\subsection{Yapısal Geçerlilik}

Çalışmada kullanılan, anket formunun yapısal geçerliliğinin test edilmesinde KMO ve Bartlett Analizleri kullanılmıştır. Tablo 3'de görüldüğü üzere çalışmada kullanılan anket formunun KMO değeri 0,681 olarak bulunmuştur. Bartlett Analizine ilişkin p değerleri ise $(p=0,000<0,05)$ olarak gerçekleşmiştir. Analizlere göre, KMO değerini 0,60 büyük olmas 1 
ve Barlett testinin anlamlı olması (p değerinin 0,05'ten küçük olması) ölçeğin yap1 geçerliliğinin olduğunu göstermektedir (Büyüköztürk, 2006: 179).

Tablo 3. KMO ve Bartlett Analizleri

\begin{tabular}{|l|l|l|}
\hline \multicolumn{2}{|l|}{ Kaiser-Meyer-Olkin Örneklem Yeterliliği Ölçümü } & ,681 \\
\hline Bartlett Küresellik Testi & Kikare & 723,210 \\
\cline { 2 - 3 } & df & 300 \\
\cline { 2 - 3 } & p &, 000 \\
\hline
\end{tabular}

\subsection{Güvenilirlik Analizi}

Güvenilirlik değeri, tekrar tekrar yapılan ölçümlerde aynı sonuca ulaşılma derecesinin bir göstergesidir. $\mathrm{Bu}$ nedenle anket soruları, güvenilirlik analizine tabi tutulmaktadır. Güvenilirlik analizinde Cronbach's Alfa katsayısından yararlanılmaktadır. İlgili katsayı 0 ile 1 arasında bir değer alır ve 1'e yaklaştıkça anketin güvenilirliği artar. Katsayının 0,70'in üzerinde olduğu durumlarda anketin güvenilir bir anket olduğu yorumu yapılmaktadır (Cihangiroğlu,2011: 11). Yapılan güvenilirlik analizi sonucunda, çalışmada kullanılan anket formunun güvenilirlik değeri Tablo 4'de de görüldüğü üzere0,70'in çok üzerinde bulunmuştur. Dolayısıyla çalışmada kullanılan ölçek, güvenilir sonuçlar vermektedir.

Tablo 4. Güvenilirlik Analizi

\begin{tabular}{|l|c|}
\hline Cronbach's Alpha & N \\
\hline ,919 & 25 \\
\hline
\end{tabular}

\subsection{Normallik Analizi}

Çalışmada kullanılacak analiz türlerinin belirlenmesi için öncelikle verilerin normal dağılım gösterip göstermediğinin belirlenmesi gerekmektedir. Verilerin normal dağılıma uygunluğu Kolmogorov-Smirnov Normallik Testi yardımıyla test edilmiştir. Yapılan normallik analizi sonucunda verilerin normal dağılıma uygun olduğu Tablo 5'de görülmüştür ( $p=0,200>0,05$ ve $Z=0,099$ ). Bu nedenle çalışmada parametrik testlerin kullanılmasına karar verilmiştir. 
Tablo 5. Normallik Analizi

\begin{tabular}{|l|l|l|}
\hline \multicolumn{2}{|l|}{} & Ölçek \\
\hline N & 47 \\
\hline \multirow{2}{*}{ Normallik Parametreleri } & Ortalama & 4,1328 \\
\cline { 2 - 3 } & Standart Sapma &, 45806 \\
\hline Aş̧rı Farklı1ıklar & Mutlak &, 099 \\
\cline { 2 - 3 } & Pozitif &, 099 \\
\cline { 2 - 3 } & Negatif &,- 063 \\
\hline Z Test İstatistiği & &, 099 \\
\hline P & &, 200 \\
\hline
\end{tabular}

\section{BULGULAR}

$\mathrm{Bu}$ kısımda araştırmanın bulgularına yer verilecektir.

\subsection{Kişisel Özellikler - Firmanın Özellikleri}

Katılımcıların yüzde 53,2'si 41 yaş ve üzerindedir. Yüzde 34'ü 34-40 yaş aralığında, yüzde 12,8’i ise 21-30 yaş aralığındadır. Bu dağılım Tablo 6'da gösterilmiştir.

Tablo 6. Katılımcıların Yaşa Göre Dağılımı

\begin{tabular}{|l|c|l|}
\hline YAŞ & N & $\%$ \\
\hline $21-30$ & 6 & 12,8 \\
\hline $31-40$ & 16 & 34,0 \\
\hline 41 ve Üzeri & 25 & 53,2 \\
\hline Total & 47 & 100,0 \\
\hline
\end{tabular}

Katılımc1ların yüzde 74,5'i ön lisans ya da lisans mezunudur. Yüzde 19,1'i lisansüstü, yüzde 6,4'ü ise lise mezunudur. Bu dağılım Tablo 7'de gösterilmiştir. 
Tablo 7. Katılımcıların Eğitim Durumuna Göre Dağılımı

\begin{tabular}{|l|c|l|}
\hline EĞİTiM & $\mathrm{N}$ & $\%$ \\
\hline Lise & 3 & 6,4 \\
\hline Ön Lisans / Lisans & 35 & 74,5 \\
\hline Lisansüstü & 9 & 19,1 \\
\hline Total & 47 & 100,0 \\
\hline
\end{tabular}

Katılımcıların yüzde 6,8'i 16 yıldan fazla mesleki deneyime sahiptir. Yüzde 19,1'i 6 ila 10 yıl arasında deneyime sahipken, yüzde 17'si 11 ila 15 yıllık mesleki geçmişe sahiptir. Bu dağılım Tablo 8'de gösterilmiştir.

Tablo 8. Katılımcıların Mesleki Deneyime Göre Dağılımı

\begin{tabular}{|l|c|l|}
\hline MESLEKİ DENEYİM & $\mathrm{N}$ & $\%$ \\
\hline $6-10$ Y1l & 9 & 19,1 \\
\hline $11-15$ Y1l & 8 & 17,0 \\
\hline 16 Y1l ve Üzeri & 30 & 63,8 \\
\hline Total & 47 & 100,0 \\
\hline
\end{tabular}

Katılımc1ların yüzde 68,1'inin firması, 16 yıldan fazla süredir faaldir. Yüzde 21,3’lük kesimin firması 11 ila 15 yıldır, yüzde 6,4'ün 6 ila 10 yıldır ve yüzde 4,3'ün 1 ila 5 yıldır faaldir. Bu dağılım Tablo 9'da gösterilmiştir.

Tablo 9. Katılımcıların Firmalarının Faaliyet Süresine Göre Dağılımı

\begin{tabular}{|l|c|l|}
\hline FAALIYET SÜRESI & $\mathrm{N}$ & $\%$ \\
\hline $1-5$ Y1l & 2 & 4,3 \\
\hline $6-10$ Yil & 3 & 6,4 \\
\hline $11-15$ Yil & 10 & 21,3 \\
\hline 16 Y1l ve Üzeri & 32 & 68,1 \\
\hline Total & 47 & 100,0 \\
\hline
\end{tabular}


Katılımcıların yüzde 63,8'inin firması tekstil sektöründe, yüzde 12,8'inin mermer sektöründe, yüzde 4,3'erlik kesimin firması ise metal ve gıda sektöründe faaliyet göstermektedir. Yüzde 14,9'luk kesimin firması ise diğer sektörlerde faaliyet halindedir. $\mathrm{Bu}$ dağılım Tablo 10'da gösterilmiştir.

Tablo 10. Katılımcıların Firmalarının Sektöre Göre Dağılımı

\begin{tabular}{|l|c|l|}
\hline SEKTÖR & $\mathrm{N}$ & $\%$ \\
\hline TEKSTILL & 30 & 63,8 \\
\hline METAL & 2 & 4,3 \\
\hline MERMER & 6 & 12,8 \\
\hline GIDA & 2 & 4,3 \\
\hline DİĞER & 7 & 14,9 \\
\hline Total & 47 & 100,0 \\
\hline
\end{tabular}

Katılımcıların yüzde 55,3'ünün firmasında ayrı bir maliyet izleme birimi bulunmaktadır. Yüzde 44,7'lik kesimin firmasında ise ayrı bir maliyet izleme birimi bulunmamaktadır. Bu dağılım Tablo 11'de gösterilmiştir.

Tablo 11. Maliyet İzleme Birimi Var mı?

\begin{tabular}{|l|c|l|}
\hline MALIYET İZLEME BİRIMII VAR MI? & $\mathrm{N}$ & $\%$ \\
\hline EVET & 26 & 55,3 \\
\hline HAYIR & 21 & 44,7 \\
\hline Total & 47 & 100,0 \\
\hline
\end{tabular}

\subsection{Frekans Analizi}

Katılımcıların anket formunda yer alan durumların stratejik karar alma üzerine etkisine ilişkin görüşlerinin dağılımları Tablo 12'degösterilmiştir. Buna göre katılımcılara göre karar alma üzerine en etkili olan durumlar;

- "Sabit ve değişken giderlerin kontrolü" (ortalama 4,62 ve standart sapma

- "Yatırım yapılacak alanların nasıl finanse edileceğinin saptanması" (ortalama 4,57 ve standart sapma 0,542 ) ve 
$0,620)$

- Bütçeler ile geliştirilmiş stratejik planlar" (ortalama 4,53 ve standart sapma olarak sıralanmıştır.

Katılımcılara göre stratejik karar almada en az etkili olan durumlar ise

- "Enflasyonist baskının üretim maliyetine olan etkisi" (ortalama 3,09 ve standart sapma 1,139),

- "Vergi yükünün birim maliyetlere olan etkisi” (ortalama 3,38 ve standart sapma 1,012) ve

- "Değer zinciri faaliyetlerinin tanımlanması" (ortalama 3,53 ve standart sapma 0,905)

olarak sıralanmıştır.

Tablo 12. Frekans Analizi

\begin{tabular}{|c|c|c|c|c|c|c|c|}
\hline Sorular & 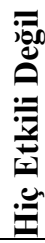 & 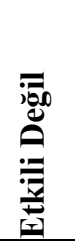 & ב⿱艹 & 击 & 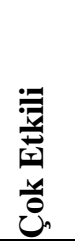 & $\frac{\pi}{\stackrel{\pi}{\pi}}$ & 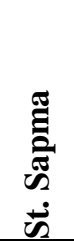 \\
\hline Sabit ve Değişken giderlerin kontrolü & & & 4,3 & 29,8 & 66,0 & 4,62 & 573 \\
\hline $\begin{array}{l}\text { Yatırım yapacağı alanların nasıl } \\
\text { finanse edileceğinin saptanması }\end{array}$ & & & 2,1 & 38,3 & 59,6 & 4,57 & ,542 \\
\hline $\begin{array}{c}\text { Bütçeler ile geliştirilmiş stratejik } \\
\text { planlar }\end{array}$ & & 2,1 & & 40,4 & 57,4 & 4,53 & ,620 \\
\hline $\begin{array}{l}\text { Maliyet ve hacim analizlerinin } \\
\text { saptanması }\end{array}$ & & 2,1 & 4,3 & 34,0 & 59,6 & 4,51 & ,688 \\
\hline $\begin{array}{c}\text { Üretimde kullanılacak işgücünün } \\
\text { nitelik ve çalışma zamanlarının } \\
\text { saptanması }\end{array}$ & & & 4,3 & 42,6 & 53,2 & 4,49 &, 585 \\
\hline $\begin{array}{l}\text { Üretim için gerekli olan hammadde ve } \\
\text { diğer girdilerin nitelik ve miktarlarının } \\
\text { saptanması }\end{array}$ & & & 8,5 & 38,3 & 53,2 & 4,45 & ,653 \\
\hline $\begin{array}{l}\text { Satılacak malların ve niteliklerinin } \\
\text { saptanması }\end{array}$ & & & 2,1 & 53,2 & 44,7 & 4,43 &, 542 \\
\hline
\end{tabular}




\begin{tabular}{|c|c|c|c|c|c|c|c|}
\hline $\begin{array}{l}\text { Kapasite, üretim hacmi ve maliyetler } \\
\text { arasındaki ilişkinin saptanması }\end{array}$ & & & & 57,4 & 42,6 & 4,43 &, 500 \\
\hline $\begin{array}{l}\text { Üretilecek mamullerin, miktarlarının } \\
\text { ve üretim zamanlarının saptanması }\end{array}$ & & 4,3 & 4,3 & 40,4 & 51,1 & 4,38 & ,768 \\
\hline $\begin{array}{c}\text { İşletmenin hangi alanlara yatırım } \\
\text { yapacağının saptanması }\end{array}$ & & 2,1 & 8,5 & 40,4 & 48,9 & 4,36 & ,735 \\
\hline Ödeme şartlarının saptanması & & & 8,5 & 48,9 & 42,6 & 4,34 & ,635 \\
\hline Genel Üretim Giderlerinin Tahmini & & 4,3 & 10,6 & 42,6 & 42,6 & 4,23 & ,813 \\
\hline Stok ve taşıma şartlarının saptanması & & 4,3 & 10,6 & 46,8 & 38,3 & 4,19 & ,798 \\
\hline Fiyat belirleme politikaları & & & 17,0 & 51,1 & 31,9 & 4,15 & ,691 \\
\hline $\begin{array}{c}\text { Alacak, stok ve duran varlık yönetim } \\
\text { politikalarının saptanması }\end{array}$ & & 2,1 & 12,8 & 57,4 & 27,7 & 4,11 & ,699 \\
\hline Kar planlama kararı ile ilgili bilgiler & & 6,4 & 10,6 & 53,2 & 29,8 & 4,06 & ,818 \\
\hline $\begin{array}{l}\text { Her faaliyetin maliyet taşıyıcılarının } \\
\text { saptanması }\end{array}$ & & 6,4 & 14,9 & 48,9 & 29,8 & 4,02 & ,847 \\
\hline Üretim akış biçiminin saptanması & & 6,4 & 14,9 & 48,9 & 29,8 & 4,02 & ,847 \\
\hline $\begin{array}{c}\text { Satış bölgelerinin ve müşterilerin } \\
\text { özelliklerinin saptanması }\end{array}$ & 4,3 & 4,3 & 17,0 & 38,3 & 36,2 & 3,98 & 1,053 \\
\hline Mamul yaşam dönemince maliyetleme & & 10,6 & 17,0 & 46,8 & 25,5 & 3,87 & ,924 \\
\hline $\begin{array}{c}\text { Katma değer sağlayan maliyetlerin } \\
\text { ortadan kalkması }\end{array}$ & & 8,5 & 29,8 & 34,0 & 27,7 & 3,81 & ,947 \\
\hline Optimal sermaye yapısının saptanması & & 10,6 & 21,3 & 48,9 & 19,1 & 3,77 & ,890 \\
\hline $\begin{array}{c}\text { Değer zinciri faaliyetlerinin } \\
\text { tanımlanması }\end{array}$ & & 12,8 & 36,2 & 36,2 & 14,9 & 3,53 & 905, \\
\hline
\end{tabular}




\begin{tabular}{|c|l|l|l|l|l|l|l|}
\hline $\begin{array}{c}\text { Vergi yükünün birim maliyetlere olan } \\
\text { etkisi }\end{array}$ & 2,1 & 17,0 & 36,2 & 29,8 & 14,9 & 3,38 & 1,012 \\
\hline $\begin{array}{c}\text { Enflasyonist baskının üretim } \\
\text { maliyetlerine olan etkisi }\end{array}$ & 2,1 & 40,4 & 17,0 & 27,7 & 12,8 & 3,09 & 1,139 \\
\hline
\end{tabular}

\subsection{Betimleyici İstatistikler}

Yönetim muhasebesi uygulamaları ile maliyet muhasebesi uygulamalarının ortalama ve standart sapma değerleri incelendiğinde Yönetim Muhasebesi uygulamalarının katılımcılar tarafından karar alma üzerinde "çok etkili" olduğu, Maliyet Muhasebesi Uygulamalarının katılımcılar tarafından karar alma üzerinde "etkili” olduğu belirtilmiştir. Bununla ilgili veriler Tablo 13'de gösterilmiştir.

Tablo 13. Betimleyici İstatistikler

\begin{tabular}{|l|l|l|l|}
\hline & N & Ortalama & St. Sapma \\
\hline Yönetim Muhasebesi Uygulamaları & $\mathbf{4 7}$ & $\mathbf{4 , 2 7 8 2}$ &, 41720 \\
\hline Maliyet Muhasebesi Uygulamaları & 47 & $\mathbf{3 , 9 7 5 2}$ &, 55165 \\
\hline Toplam & 47 & 4,1328 &, 45806 \\
\hline
\end{tabular}

\subsection{Vardamsal (Yordayıcı)Analizler}

$\mathrm{Bu}$ kısımda yordayıcı analizlere yer verilecektir.

\subsubsection{Yönetim Muhasebesinin Karar Alma Üzerine Etkisine Yönelik Analizler}

Yönetim muhasebesinin karar alma üzerine etkisinin, katılımcıların yaşlarına göre farklılık gösterip göstermediğinin belirlenmesi için ANOVA analizinden faydalanılmıştır. Yapılan analiz sonucunda katılımcıların yönetim muhasebesinin karar alma üzerine etkisine yönelik görüşleri, yaşlarına göre farkl1lık göstermemektedir $(\mathrm{p}=0,089>0,05) . \mathrm{Bu}$ sonuçlarla,farklı yaş katmanındaki mali işler müdürlerinin yönetim muhasebesine hemen hemen aynı perspektifte baktığını görmekteyiz. 
Tablo 14. Yönetim Muhasebesinin Karar Alma Üzerine Etkisi / Yaş ANOVA

\begin{tabular}{|l|l|l|l|l|l|}
\hline & N & Ortalama & St. Sapma & F & Sig. \\
\hline $21-30$ & 6 & 4,4487 &, 35223 & 2,556 &, 089 \\
\hline $31-40$ & 16 & 4,4087 &, 32237 & & \\
\hline 41 ve Üzeri & 25 & 4,1538 &, 45617 & & \\
\hline Total & 47 & 4,2782 &, 41720 & & \\
\hline
\end{tabular}

Yönetim muhasebesinin karar alma üzerine etkisinin, katılımcıların öğrenim durumlarına göre farklılık gösterip göstermediğinin belirlenmesi için ANOVA analizinden faydalanılmıştır. Yapılan analiz sonucunda katılımcıların yönetim muhasebesinin karar alma üzerine etkisine yönelik görüşleri, öğrenim durumlarına göre farklılık göstermemektedir $(\mathrm{p}=0,105>0,05)$.

Tablo 15. Yönetim Muhasebesinin Karar Alma Üzerine Etkisi / Öğrenim Durumu ANOVA

\begin{tabular}{|l|l|l|l|l|l|}
\hline & N & Ortalama & St. Sapma & F & p \\
\hline Lise & 3 & 4,7436 &, 17765 & 2,372 &, 105 \\
\hline Ön Lisans ve Lisans & 35 & 4,2242 &, 44085 & & \\
\hline Lisansüstü & 9 & 4,3333 &, 26368 & & \\
\hline Total & 47 & 4,2782 &, 41720 & & \\
\hline
\end{tabular}

Yönetim muhasebesinin karar alma üzerine etkisinin, katılımcıların mesleki deneyimlerine göre farklılık gösterip göstermediğinin belirlenmesi için ANOVA analizinden faydalanılmıştır. Yapılan analiz sonucunda katılımcıların yönetim muhasebesinin karar alma üzerine etkisine yönelik görüşleri, mesleki deneyimlerine göre farklılık göstermemektedir $(\mathrm{p}=0,070>0,05)$. 
Tablo 16. Yönetim Muhasebesinin Karar Alma Üzerine Etkisi / Mesleki Deneyim ANOVA

\begin{tabular}{|l|l|l|l|l|l|}
\hline & N & Ortalama & St. Sapma & F & P \\
\hline 6-10 Y1l & 9 & 4,5470 &, 33847 & 2,825 &, 070 \\
\hline $11-15$ Y1l & 8 & 4,3173 &, 30614 & & \\
\hline 16 Y1l Ve Üzeri & 30 & 4,1872 &, 43640 & & \\
\hline Total & 47 & 4,2782 &, 41720 & & \\
\hline
\end{tabular}

Yönetim muhasebesinin karar alma üzerine etkisinin, katılımcıların firmalarının faaliyet süresine göre farklılık gösterip göstermediğinin belirlenmesi için ANOVA analizinden faydalanılmıştır. Yapılan analiz sonucunda katılımcıların yönetim muhasebesinin karar alma üzerine etkisine yönelik görüşleri, firmalarının faaliyet süresine göre farklılık göstermemektedir $(\mathrm{p}=0,323>0,05)$.

Tablo 17. Yönetim Muhasebesinin Karar Alma Üzerine Etkisi / Firma Faaliyet Süresi ANOVA

\begin{tabular}{|l|l|l|l|l|l|}
\hline & N & Ortalama & St. Sapma & F & p \\
\hline 1-5 Y1l & 2 & 4,8077 &, 16318 & 1,194 &, 323 \\
\hline $6-10$ Y1l & 3 & 4,3333 &, 51218 & & \\
\hline 11-15 Y1l & 10 & 4,2769 &, 32676 & & \\
\hline 16 Y1l Ve Üzeri & 32 & 4,2404 &, 43547 & & \\
\hline Total & 47 & 4,2782 &, 41720 & & \\
\hline
\end{tabular}

Yönetim muhasebesinin karar alma üzerine etkisinin, katılımcıların firmalarının sektörüne göre farklılık gösterip göstermediğinin belirlenmesi için ANOVA analizinden faydalanılmıştır. Yapılan analiz sonucunda katılımcıların yönetim muhasebesinin karar alma üzerine etkisine yönelik görüşleri, firmalarının sektörüne göre farklılık göstermektedir $(\mathrm{p}=0,017<0,05)$. Bu farklılığın kaynağının tespit edilebilmesi için gerçekleştirilen Tukey Çözümlemesi sonucunda ise diğer sektörlerde faaliyet gösteren firmaların, tekstil sektörü başta olmak üzere metal, mermer, gıda sektörüne göre yönetim muhasebesi uygulamalarının, karar alma üzerinde daha fazla etki ettiği görülmüştür. 
Tablo 18: Yönetim Muhasebesinin Karar Alma Üzerine Etkisi / Firma Faaliyet Alanı ANOVA

\begin{tabular}{|l|l|l|l|l|l|l|}
\hline & N & Ortalama & St. Sapma & F & p & Fark \\
\hline Tekstil & 30 & $\mathbf{4 , 1 6 9 2}$ &, 37976 & 3,388 & $\mathbf{, 0 1 7}$ & $1-5$ \\
\hline Metal & 2 & 4,0769 &, 54393 & & & \\
\hline Mermer & 6 & 4,3077 &, 41281 & & & \\
\hline G1da & 2 & 4,4231 &, 59832 & & & \\
\hline Diğer & 7 & $\mathbf{4 , 7 3 6 3}$ &, 24670 & & & \\
\hline Total & 47 & 4,2782 &, 41720 & & & \\
\hline
\end{tabular}

Yönetim muhasebesinin karar alma üzerine etkisinin, katılımcıların firmalarında ayrı bir maliyet izleme birimi olup olmamasına göre farklılık gösterip göstermediğinin belirlenmesi için Bağımsız Örneklem T testinden faydalanılmıştır. Yapılan analiz sonucunda katılımcıların yönetim muhasebesinin karar alma üzerine etkisine yönelik görüşleri, firmalarında ayrı bir maliyet izleme birimi olup olmamasına göre farklılık göstermemektedir $(p=0,959>0,05)$.

Tablo 19. Yönetim Muhasebesi / Maliyet İzleme Birimi Olma T Testi

\begin{tabular}{|l|l|l|l|l|l|l|}
\hline \multicolumn{2}{|l|}{ Maliyet İzleme Birimi Var mı? } & N & Ortalama & St. Sapma & t & p \\
\hline Yönetim Muhasebesi Uygulamaları & Evet & 26 & 4,2811 &, 40759 &, 051 &, 959 \\
\cline { 2 - 7 } & Hayır & 21 & 4,2747 &, 43891 & & \\
\hline
\end{tabular}

\subsubsection{Maliyet Muhasebesinin Karar Alma Üzerine Etkisine Yönelik Analizler}

Maliyet muhasebesinin karar alma üzerine etkisinin, katılımcıların yaşlarına göre farklılık gösterip göstermediğinin belirlenmesi için ANOVA analizinden faydalanılmıştır. Yapılan analiz sonucunda katılımcıların maliyet muhasebesinin karar alma üzerine etkisine yönelik görüşleri, yaşlarına göre farklılık göstermemektedir ( $\mathrm{p}=0,187>0,05)$. 
Tablo 20. Maliyet Muhasebesinin Karar Alma Üzerine Etkisi / Yaş ANOVA

\begin{tabular}{|l|l|l|l|l|l|}
\hline & N & Ortalama & St. Sapma & F & P \\
\hline $21-30$ & 6 & 4,2083 &, 32808 & 1,744 &, 187 \\
\hline $31-40$ & 16 & 4,0990 &, 53767 & & \\
\hline 41 ve Üzeri & 25 & 3,8400 &, 58081 & & \\
\hline Total & 47 & 3,9752 &, 55165 & & \\
\hline
\end{tabular}

Maliyet muhasebesinin karar alma üzerine etkisinin, katılımcıların öğrenim durumlarına göre farklılık gösterip göstermediğinin belirlenmesi için ANOVA analizinden faydalanılmıştır. Yapılan analiz sonucunda katılımcıların maliyet muhasebesinin karar alma üzerine etkisine yönelik görüşleri, öğrenim durumlarına göre farklılık göstermemektedir $(p=0,196>0,05)$.

Tablo 21. Maliyet Muhasebesinin Karar Alma Üzerine Etkisi / Öğrenim Durumu ANOVA

\begin{tabular}{|l|l|l|l|l|l|}
\hline & N & Ortalama & St. Sapma & F & p \\
\hline Lise & 3 & 4,5278 &, 31549 & 1,693 &, 196 \\
\hline Ön Lisans Ve Lisans & 35 & 3,9262 &, 58220 & & \\
\hline Lisansüstü & 9 & 3,9815 &, 39917 & & \\
\hline Total & 47 & 3,9752 &, 55165 & & \\
\hline
\end{tabular}

Maliyet muhasebesinin karar alma üzerine etkisinin, katılımcıların mesleki deneyimlerine göre farklılık gösterip göstermediğinin belirlenmesi için ANOVA analizinden faydalanılmıştır. Yapılan analiz sonucunda katılımcıların maliyet muhasebesinin karar alma üzerine etkisine yönelik görüşleri, mesleki deneyimlerine göre farklılık göstermemektedir $(\mathrm{p}=0,075>0,05)$. 
Tablo 22. Maliyet Muhasebesinin Karar Alma Üzerine Etkisi / Mesleki Deneyim ANOVA

\begin{tabular}{|l|l|l|l|l|l|}
\hline & N & Ortalama & St. Sapma & F & P \\
\hline 6-10 Y1l & 9 & 4,2963 &, 42921 & 2,755 &, 075 \\
\hline 11-15 Y1l & 8 & 3,6979 &, 27436 & & \\
\hline 16 Y1l ve Üzeri & 30 & 3,9528 &, 60000 & & \\
\hline Total & 47 & 3,9752 &, 55165 & & \\
\hline
\end{tabular}

Maliyet muhasebesinin karar alma üzerine etkisinin, katılımcıların firmasının faaliyet süresine göre farklılık gösterip göstermediğinin belirlenmesi için ANOVA analizinden faydalanılmıştır. Yapılan analiz sonucunda katılımcıların maliyet muhasebesinin karar alma üzerine etkisine yönelik görüşleri, firmasının faaliyet süresine göre farklılık göstermemektedir $(\mathrm{p}=0,133>0,05)$.

Tablo 23. Maliyet Muhasebesinin Karar Alma Üzerine Etkisi / Firma Faaliyet Süresi ANOVA

\begin{tabular}{|l|l|l|l|l|l|}
\hline & N & Ortalama & St. Sapma & F & P \\
\hline 1-5 Y1l & 2 & 4,5000 &, 23570 & 1,969 &, 133 \\
\hline $6-10$ Y1l & 3 & 4,0833 &, 58333 & & \\
\hline 11-15 Y1l & 10 & 3,6583 &, 28178 & & \\
\hline 16 Y1l Ve Üzeri & 32 & 4,0313 &, 59182 & & \\
\hline Total & 47 & 3,9752 &, 55165 & & \\
\hline
\end{tabular}

Maliyet muhasebesinin karar alma üzerine etkisinin, katılımcıların firmasının faaliyet alanına göre farklılık gösterip göstermediğinin belirlenmesi için ANOVA analizinden faydalanılmıştır. Yapılan analiz sonucunda katılımcıların maliyet muhasebesinin karar alma üzerine etkisine yönelik görüşleri, firmasının faaliyet alanına göre farklılık göstermemektedir $(\mathrm{p}=0,059>0,05)$. 
Tablo 24. Maliyet Muhasebesinin Karar Alma Üzerine Etkisi / Firma Faaliyet Alanı ANOVA

\begin{tabular}{|l|l|l|l|l|l|}
\hline & N & Ortalama & St. Sapma & F & p \\
\hline TEKSTİL & 30 & 3,8361 &, 54863 & 2,476 &, 059 \\
\hline METAL & 2 & 3,9583 &, 53033 & & \\
\hline MERMER & 6 & 3,9861 &, 39936 & & \\
\hline GIDA & 2 & 4,1667 &, 70711 & & \\
\hline DİĞER & 7 & 4,5119 &, 41228 & & \\
\hline Total & 47 & 3,9752 &, 55165 & & \\
\hline
\end{tabular}

Yönetim muhasebesinin karar alma üzerine etkisinin, katılımcıların firmalarında ayrı bir maliyet izleme birimi olup olmamasına göre farklılık gösterip göstermediğinin belirlenmesi için Bağımsız Örneklem T testinden faydalanılmıştır. Yapılan analiz sonucunda katılımcıların yönetim muhasebesinin karar alma üzerine etkisine yönelik görüşleri, firmalarında ayrı bir maliyet izleme birimi olup olmamasına göre farklılık göstermemektedir $(\mathrm{p}=0,887>0,05)$.

Tablo 25. Maliyet Muhasebesi / Maliyet İzleme Birimi OlmaT Testi

\begin{tabular}{|l|l|l|l|l|l|l|}
\hline \multicolumn{2}{|l|}{ Maliyet İzleme Birimi Var mı? } & N & Ortalama & St. Sapma & t & p \\
\hline Maliyet Muhasebesi Uygulamaları & Evet & 26 & 3,9647 &, 59543 &,- 143 &, 887 \\
\cline { 2 - 8 } & Hayır & 21 & 3,9881 &, 50641 & & \\
\hline
\end{tabular}

\section{SONUÇ}

Günümüzde teknolojik ilerlemeler işletmelerin çetin rekabet koşullarıyla baş başa kalmasına neden olmaktadır. Yaşanan gelişmeler nedeniyle işletmeler, yönetim stratejilerini yeniden elden geçirme gereksinimi duymuştur. $\mathrm{Bu}$ nedenle KOBI'lerin artan rekabet şartlarına uyum sağlamaları, endüstri işletmelerinin değer zinciri içerisinde kalabilmeleri, maliyetlerini yönetebilmelerine bağlıdır. Bu doğrultuda KOBİ'lerin mevcut yetersiz maliyet ve yönetim muhasebesi sistemlerini gözden geçirerek gelişmiş endüstriyel ortamın gereksinimlerini karşılayan yeni maliyet ve yönetim muhasebesi yöntemlerini kullanarak, bu sistemleri bünyelerine taşımaları zorunlu hale gelmiştir. İşletmelerde gerek stratejik, gerek yönetsel ve gerekse teknik kararların da büyük bir kısmı yine maliyetlerle ilgilidir. Bu nedenle işletmelerin, etkin bir maliyet azaltma programını uygulamaya koymaları halinde, işletmenin 
amaçlarına ulaşması daha da kolaylaşır. Dolayısıyla kıt kaynaklara sahip KOBİ'lerin stratejik karar almasında yönetim ve maliyet muhasebesi uygulamalarının büyük önemi vardır. Küçük ölçekli işletmelerde karar alma işlemi, işletme sahibince veya ortaklarca yerine getirilebilir. Orta boy işletmelerde ise yetki, kısmen de olsa yönetici veya astlara devredildiğinden kararlar birlikte alınmaktadır. Ne var ki, son söz üst yönetimindir. Bu nedenle KOBİ'lerde karar alınırken, büyük ölçekli işletmelere oranla bilimsel teknikler daha az kullanılabilmektedir. Buna karşın hızlı ve esnek kararlar alınabilmektedir. Ancak uygulama çalışmalarının da gösterdiği gibi KOBİ'lerde özellikle muhasebe bilgi sistemlerine gerekli özenin gösterilmemesi, stratejik karar sürecinde zorluklar yaşanmasına neden olmaktadır. Bu nedenle KOBİ'lerin daha etkin şekilde bilgilendirilmesinin büyük önemi bulunmaktadır.

KOBİ'lerin stratejik karar almalarında yönetim ve maliyet muhasebesi uygulamalarının etkisine yönelik olarak Denizli Organize Sanayi Bölgesi’ndeki işletmeler özelinde gerçekleştirilen araştırmanın sonuçlarına göre KOBİ'lerin stratejik kararlarında yönetim muhasebesi uygulamaları çok etkilidir. Maliyet muhasebesi uygulamaları ise etkili olarak değerlendirilmiştir. Araştırma kapsamında yanıtı aranan alt sorulardan ise yalnızca yönetim muhasebesinin etkisine yönelik görüşler, işletmenin faaliyet alanına göre farklılık göstermektedir. Buna göre "diğer" alanlarda faaliyet gösterenler, "tekstil" sektöründe faaliyet gösterenler başta olmak üzere gıda, mermer, metal sektörlerine göre yönetim muhasebesinin stratejik karar alma üzerine daha etkili olduğunu düşünmektedir. Bulgulara göre Denizli Organize Sanayi Bölgesi'ndeki KOBİ'lerin stratejik karar almalarında yönetim muhasebesi uygulamaları etkilidir. Yönetim muhasebesi uygulamaları, maliyetleri düşürmek ve verimliliği arttırmak amaçlı kullanıldığından, işletmelerin yerinde ve doğru anda karar almalarına olanak sağlamaktadır. Yönetim muhasebesi uygulamaları ayrıca işletmelerde yoğun rekabet koşullarında ayakta kalabilmeleri ve faaliyet risklerini minimize edebilmelerini sağlamaktadır.

Maliyet muhasebesi uygulamaları ise yönetim muhasebesi uygulamalarına yardımcı niteliktedir. Maliyet muhasebesi uygulamaları işletmelerin katlandıkları fiili maliyetleri, yönetim muhasebesine yardımcı olması bakımından ortaya koymaktadır. İşletmelerin maliyetlerini hesaplayarak piyasadaki yenilikleri takip etmesi, rekabet gücüne olumlu yansıyacaktır. Ayrıca doğru anda kullanılacak maliyet muhasebesi uygulamaları ile işletmelerin karlılık analizleri daha sağlıklı olarak gerçekleştirilebilecektir.

Araştırma kapsamındaki işletmeler de stratejik kararlar alırken yönetim muhasebesi uygulamalarını çok etkili şekilde kullanmaktadır. Maliyet muhasebesi uygulamaları ise, yönetim muhasebesi uygulamalarına yardımcı olma niteliğinde olmasının da bir yansıması olarak Denizli'deki işletmeler için yönetim muhasebesine göre daha az etkili olarak nitelendirilmiştir. Ancak bu iki uygulama, birbirinden çok farklı gibi düşünülmemeli, bir bütün olarak ele alınmalıdır.

Sonuç olarak, günümüzün çetin rekabet koşullarında işletmelerin ayakta kalabilmeleri için doğru anda doğru kararı alabilmeleri şarttır. Bu kararın alınmasında ise yönetim ve 
maliyet muhasebesi uygulamalarından yararlanılmaktadır. Doğru anda doğru kararı alabilmek için yönetim ve maliyet muhasebesi uygulamaları birlikte kullanılmalıdır. Ancak bu şekilde isabetli karar söz konusu olabilecektir. Bundan sonra yapılacak çalışmalarda yönetim ve maliyet muhasebesinin hangi stratejik kararlarda daha etkili olduğu konusunda çalışmalar yapılabilir ve bunun nedenleri analiz edilebilir. Yani maliyet ve yönetim muhasebesinin stratejik karar üzerindeki etkisi daha derinleştirilebilir. Bunun yanı sıra stratejik kararların başarılı olmasında, yönetim ve maliyet muhasebesinde işletmenin ne tür değişimlere ve yeniliklere gitmesi gerektiği konusunda ve bunun tespiti için yapılması gereken çalışmalar üzerine birtakım araştırmalar yapılabilir.

\section{KAYNAKLAR}

Ah Lay, Tan - Jusoh, Ruzita (2011),“Business Strategy, Strategic Role of Accountant, Strategic Management Accounting and Their Links to Firm Performance: An Explotary Study of Manufacturing Companies in Malaysia”. Proceeding. Accounting Researchand Education Conference.

Akgemci, Tahir - Öğüt, Âdem - Tosun, Mevhibe (2005) "Küresel Rekabetin Sunduğu Frrsatlar ve Tehditler Bağlamında KOBİlerde Stratejik Yenilik Yönetimi: SWOT Analizine Dayalı Kuramsal Bir Değerlendirme", S.Ü. İİBF Sosyal ve Ekonomik Araştırmalar Dergisi, Cilt 10, ss. 139-156.

Aktan, Coşkun Can (2008) "Stratejik Yönetim ve Stratejik Planlama”, Çimento İşveren Dergisi, 22 (4), ss. 4-21.

Aktaş, Rabia (2013) "Yeni Bir Maliyet ve Yönetim Muhasebesi Yöntemi Olarak Kaynak Tüketim Muhasebesi”, Muhasebe ve Finans Dergisi, Cilt 15, Sayı 58, ss. 55-76.

Alagöz, Ali - Öge, Serdar - Koçyiğit, Nezahat (2013) "Muhasebe Bilgi Sistemi ve Karar Destek Sistemleri İlişkisinin Yönetsel Karar Alma Faaliyetlerine Etkisi”, Selçuk Üniversitesi SBE Dergisi, Sayı 30, ss. 27-40.

AlMaryani, Majeed A. Hatif - Sadik, Hamza H. (2012). "Strategic management accounting techniques in Romanian Companies: some surveyevidence”, Procedia Economicsand Finance, 3,pp. 387-396.

Altuğ, Osman (2006). Maliyet Muhasebesi. Türkmen Kitabevi: İstanbul.

Banham, Heather (2010) "External Environmental Analysis For Small And Medium Enterprises (SMEs)”, Journal of Business \&Economics Research, Cilt 8, No 10, pp. 19-26. 
Bayri, Osman (2005). "Maliyet Liderliği Stratejisi Açısından Maliyet-Hacim Analizleri”. Muhasebe ve Finansman Dergisi, (28), ss. 184-197.

Boran, Abdurrahman (2015) "Din Kültürü ve Ahlak Bilgisi Öğretmenlerinin Diğer Dinlere Ait İbadet, Çağrı Usulü ve Kitaplarının Satılması ile İlgili Düşünce ve Tutumları”, KSÜ Sosyal Bilimler Dergisi, Cilt: 13, Sayı: 1, ss. 199-218.

Büyüköztürk, Şener (2006). Veri Analizi El Kitabı, 6. Baskı, Ankara: Pegem A Yayıncılık.

Canbaz, Serdar (2014), “KOBİ’lerde Stratejik Planlama ve Karar Alma Sürecinde Yönetim Bilgi Sistemlerinin Rolü ve Önemi: Edirne'de Bir Araştırma” (Yayımlanmamış Doktora Tezi), Trakya Üniversitesi SBE.

Chang, Shen-Ho - Chiu, An-An - Chu, Chu Ling - Wang, Teng-Shih, - Hsieh, Sung-I(2015) "Material Flow Cost Accounting System for Decision Making: The Case of Taiwan SME in the Metal Processing Industry”, Asian Journal of Finance and Accounting, Cilt 7, Sayı 1, pp. 117-134.

Cihangiroğlu, Necmettin (2011). “Askeri doktorların örgütsel adalet algıları ile örgütsel bağlılıkları arasındaki ilişkinin analizi”. Gülhane Tıp Dergisi, 53(1), ss. 9-16.

Ibarrondo-Dávila, M. P. - López-Alonso, M. - Rubio-Gámez, M. C. (2015). “Managerial accounting for safety management. The case of a Spanish construction company”. Safety science, 79, pp. 116-125.

Dekker, Henri C. (2016). "On the boundaries between intrafirm and interfirm management accounting research”. Management Accounting Research, 31, pp. 86-99.

Demir Hulusi - Gümüşoğlu, Şevkinaz (1998),Üretim Yönetimi, İstanbul: Alfa Yayınları.

Demir, Özcan - Gül, Meltem (2015) “Üretim Yapan KOBİ’lerde Karar Sürecinde Muhasebe Bilgi Sisteminin Etkileri: TRB1 Bölgesinde Yapılan Bir Araştırma”, Fırat Üniversitesi Sosyal Bilimler Dergisi, Cilt. 25, Say1. 2, ss. 171-191.

Demir, Volkan (2008). "Yönetim Muhasebesindeki Değişim ve Değişimi Etkileyen Faktörler”. Muhasebe ve Denetime Bakış Dergisi, 8, ss. 26-51.

Demirkutlu, Fatma Karakaya (2015). "Maliyet Yönetimi ve KOBİ'lerin Farkındalıkları: Ampirik Bir Çalışma”. Gazi Üniversitesi Sosyal Bilimler Dergisi, 2(2), ss. 39-62.

Ehtiyar, V. Rüya- Tekin, Akgün Ömer (2010), "Yönetimde Karar Verme: Batı Antalya Bölgesindeki Beş Yıldızlı Otellerde Çalışan Farklı Departman Yöneticilerinin Karar Verme Stilleri Üzerine Bir Araştırma”. Yaşar Üniversitesi, 5 (20), ss. 3395-3414.

Erdoğan Necmettin - Saban Metin (2014),Maliyet ve Yönetim Muhasebesi, İstanbul: Yazın Basın Yayın Matbaacılık.

Hatunoğlu, Zeynep - Akpınar, Yusuf - Çelik, Adnan (2013). “KOBİ'lerin Yönetiminde Muhasebe Bilgi Sisteminin Önemi: Gaziantep ve Kahramanmaraş Örneği”. Niğde Üniversitesi İktisadi ve İdari Bilimler Fakültesi Dergisi, 6(2), ss. 307-322. 
İzci, Çağrı (2014). "Muhasebe Verilerinin İşletmelerin Stratejik Yönetim Ve Karar Alma Sürecinde Kullanımı ve Önemi”. Yönetim ve Ekonomi Araştırmaları Dergisi, 12(23), Ss. $188-206$.

Jänkälä, Sinikka - Silvola, Hanna (2012). "Lagging Effects of the Use of Activity Costing on the Financial Performance of Small Firms”. Journal of Small Business Management, 50(3), pp. 498-523.

Kalkan, V. Denizhan - Keskin, Halit (2005) “KOBİ'lerde Bilgi Yönetimi Süreci ve Araçları: Literatür Değerlendirmesi ve Bir Araştırma”, Bilig Dergisi, Sayı 35, ss. 173-206.

Karaoğlu Batuhan (2010),Stratejik Yönetim, İstanbul: Etap Yayınevi.

Koçel, Tamer (2003), İşletme Yöneticiliği, Geliştirilmiş Dokuzuncu Baskı. Beta Basım Yayım AŞ, İstanbul.

Koçel, Tamer (2013), İşletme Yöneticiliği, 14. Baskı. Beta Basım Yayım AŞ, İstanbul.

Kraus, Sascha - Reiche, B. Sebastian-Reschke, Carl Henning (2007), "Implication of Strategic Planning in SMEs for International Entrepreneurship Research and Practice”,EuropeanResearchandPractice, Cilt 32, Sayı 6, pp. 110-127

Laitinen, Erkki K. (2014). "Influence of cost accounting change on performance of manufacturing firms”. Advances in Accounting, 30(1), pp. 230-240.

Ma, Yi - Tayles, Mike(2009). "On the emergence of strategic management accounting: an institutionalperspective”. Accounting and Business Research, 39(5), pp. 473-495.

Maiga, Adam S. - Jacobs, Fred A. (2008). "Extent of ABC use and itsconsequences”. Contemporary Accounting Research, 25(2), pp. 533-566.

Mihăilă, Mădălina (2014). "Managerial accounting and decisionmaking, in energyindustry”. Procedia-Socialand Behavioral Sciences, 109, pp. 1199-1202.

Oliver, Lianabel (1999),Cost Management Toolbox, New York: AMACOM.

Titiz, İsmet - Çetin, A. Cüneyt (2000). "Karar Almada Geleneksel Maliyet Yönetimi Yaklaşımında Yaşanan Gelişmeler ve Stratejik Maliyet Yönetimi”. Süleyman Demirel Üniversitesi İktisadi ve İdari Bilimler Fakültesi Dergisi, 5(2), ss. 121-138.

TÜIKK (2016). Küçük ve Orta Büyüklükteki Girişim İstatistikleri, 2015. http://www.tuik.gov.tr/PreHaberBultenleri.do?id=21864, Erişim Tarihi: 13.11.2016.

Uyar, Ali (2010) “Costand Management Accounting Practices”, Eurasian Journal of Business and Economics, Cilt 3, Say16, ss. 113-125.

Wheelen, L. Thomas- Hunger J. David (1989), Strategic Management and Business Policy, Addison-Wesley Publishing Company.

Yazıc1, Nusret (2010). "Bir Bilgi Sistemi Olarak Muhasebenin KOBİ'lerin Yönetim Kararlarına Etkisi: Erzurum Araştırması”. MUFAD, 47, ss. 202,212. 
Yükçü, Süleyman (1998) Yönetim Açısından Maliyet Muhasebesi, İzmir: Anadolu Matbaacilik.

Yüzbaşığlu, Nedim (2004) "İşletmelerde Stratejik Yönetim ve Planlama Açısından Stratejik Maliyet Yönetimi ve Enstrümanları”, Selçuk Üniversitesi SBE Dergisi, Sayı 12, ss. 387-410.

Zenita, Raisya - Sari, Ria Nelly - Anugerah, Rita - Said, Jamaliah (2015). “TheEffect of Information Literacy on Managerial Performance: TheMediating Role of Strategic Management Accounting and the Moderating Role of Self Efficacy”. Procedia Economicsand Finance, 31,pp. 199-205. 
EKLER

\section{Ek.1 Anket Formu}

\section{Sayın Katılımcılar,}

$\mathrm{Bu}$ çalışma; "KOBİLERDE YÖNETIM VE MALIYYET MUHASEBESININ STRATEJIKK KARAR ALMA ÜZERINE ETKİSI" Yapılan araştırma tamamıyla akademik nitelikli olup çalışmadan elde edilecek bilgiler bilimsel amaca yönelik olarak kullanılacak ve alınan cevaplar kesinlikle gizli tutulacaktır.

Çalışmaya yapacağınız değerli katkılarınızdan dolayı şimdiden teşekkür eder, saygılarımı sunarım.

\section{BÖL ÜM}

Lütfen aşağıda yer alan kişisel bilgilerinizi belirtiniz.

Yaş Grubunuz?
( ) $21-30$
( ) $31-40$
( ) 41 ve üzeri

Eğitim Durumunuz?

( ) İlköğretim ve altı ( ) Lise ～～～～～Lisans ve önlisans ～～～Lisansüstü

Mesleki Deneyiminiz?
( ) 1-5 y1l
( ) 6-10
( ) $11-15$
( ) 16 ve üzeri

Firmanızın faaliyet süresi?
( ) $1-5 \mathrm{y} 11$
( ) $6-10$
( ) $11-15$
( ) 16 ve üzeri

İşletmelerin Faaliyette Bulunduğu Sektörlere Göre Dağılımları

Tekstil ( ) Metal ( ) Mermer ( ) Gida ( ) $\quad \operatorname{Diğer}($ )

İşletmede Maliyetlerin İzlendiği Ayrı Birim var mı?

Evet ( ) Hayır ( ) 


\section{BÖLÜM: YÖNETIM VE MALIYET MUHASEBESININ STRATEJIKK KARAR ALMA ÜZERINE ETKİSi}

Yönetim ve maliyet muhasebesine ait gelişmeler ve bilgi seviyesinin stratejik karar alırken etkisini en iyi yansıtan seçeneği (X) ile işaretleyiniz.

\begin{tabular}{|c|c|c|c|c|c|c|}
\hline S.N. & SORULAR & 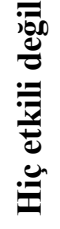 & 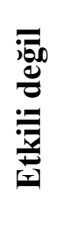 & 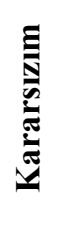 & 望 & 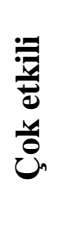 \\
\hline 1 & Bütçeler ile geliştirilmiş stratejik planlar & & & & & \\
\hline 2 & Satılacak malların ve niteliklerinin saptanması & & & & & \\
\hline 3 & Satış bölgelerinin ve müşterilerin özelliklerinin saptanması & & & & & \\
\hline 4 & Üretilecek mamullerin, miktarlarının ve üretim zamanlarının saptanması & & & & & \\
\hline 5 & $\begin{array}{l}\text { Üretim için gerekli olan hammadde ve diğer girdilerin nitelik ve } \\
\text { miktarlarının saptanması }\end{array}$ & & & & & \\
\hline 6 & $\begin{array}{l}\text { Üretimde kullanılacak işgücünün nitelik ve çalışma zamanlarının } \\
\text { saptanması }\end{array}$ & & & & & \\
\hline 7 & Üretim akış biçiminin saptanması & & & & & \\
\hline 8 & Ödeme şartlarının saptanması & & & & & \\
\hline 9 & Stok ve taşıma şartlarının saptanması & & & & & \\
\hline 10 & İşletmenin hangi alanlara yatırım yapacağının saptanması & & & & & \\
\hline 11 & Optimal sermaye yapısının saptanması & & & & & \\
\hline 12 & Alacak, stok ve duran varlık yönetim politikalarının saptanması & & & & & \\
\hline 13 & Yatırım yapacağı alanların nasıl finanse edileceğinin saptanması & & & & & \\
\hline 14 & Kar planlama kararı ile ilgili bilgiler & & & & & \\
\hline 15 & Değer zinciri faaliyetlerinin tanımlanması & & & & & \\
\hline 16 & Her faaliyetin maliyet taşıyıcılarının saptanması & & & & & \\
\hline 17 & Katma değer sağlayan maliyetlerin ortadan kalkması & & & & & \\
\hline 18 & Mamul yaşam dönemince maliyetleme & & & & & \\
\hline 19 & Sabit ve Değişken giderlerin kontrolü & & & & & \\
\hline 20 & Kapasite, üretim hacmi ve maliyetler arasındaki ilişkinin saptanması & & & & & \\
\hline 21 & Maliyet ve hacim analizlerinin saptanması & & & & & \\
\hline 22 & Fiyat belirleme politikaları & & & & & \\
\hline 23 & Genel Üretim Giderlerinin Tahmini & & & & & \\
\hline 24 & Enflasyonist baskının üretim maliyetlerine olan etkisi & & & & & \\
\hline 25 & Vergi yükünün birim maliyetlere olan etkisi & & & & & \\
\hline
\end{tabular}

